\title{
Veseátültetés utáni sebészeti szövődmények előfordulása a Clavien-beosztás szerint, különös tekintettel
} a húgyvezeték-anastomosis típusára

\author{
Illésy Lóránt dr. ${ }^{1}$ - Fedor Roland $d r^{1}{ }^{1}$ Kovács Dávid Ágoston dr. ${ }^{1}$ \\ Kanyári Zsolt dr. ${ }^{1}$ - Zádori Gergely dr. ${ }^{1}$ - Szőllősi Gergő József ${ }^{2}$ \\ Kovács Márton oh. ${ }^{3}$. Flaskó Tibor dr. ${ }^{4}$. Tóth Judit dr. ${ }^{5}$ \\ Veisz Richárd dr. ${ }^{5}$ - Belán Ivett dr. ${ }^{5}$ - Nemes Balázs dr. ${ }^{1}$ \\ ${ }^{1}$ Debreceni Egyetem, Általános Orvostudományi Kar, Sebészeti Intézet, \\ Szervtranszplantációs Nem Önálló Tanszék, Debrecen \\ ${ }^{2}$ Debreceni Egyetem, Népegészségügyi Kar, Debrecen \\ ${ }^{3}$ Debreceni Egyetem, Általános Orvostudományi Kar, Általános Orvos Szak, Debrecen \\ ${ }^{4}$ Debreceni Egyetem, Általános Orvostudományi Kar, Urológiai Tanszék, Debrecen \\ ${ }^{5}$ Debreceni Egyetem, Általános Orvostudományi Kar, Orvosi Képalkotó Intézet, Debrecen
}

\begin{abstract}
Bevezetés: Veseátültetést követően a graft és a beteg túlélésére hatással lehetnek a posztoperatív intervenciót igényló szövődmények. Fontos szempont a mútéttechnikai eredményesség monitorozása. Többek között az irodalomban számos lehetőség ismert a veseátültetés sarokpontjának számító ureteranastomosis elkészítésére is, de az éranastomosisok technikája szintén döntő lehet.

Célkitüzés és módszer: Retrospektíven vizsgáltuk a 2010 és 2020 között végzett veseátültetéseket a Debreceni Egyetem Sebészeti Klinikáján. Célul tûztük ki a sebészeti szövődmények vizsgálatát, melyeket rendszereztünk, a módosított Clavien-féle beosztás alapján. A legnagyobb figyelmet az ureteranastomosisokra fordítottuk. Minden betegnél az adott kategóriában legsúlyosabb szövődményt vettük alapul a beosztáshoz. A minimális utánkövetési idő 1 év volt. Az adatokat az SPSS statisztikai program segítségével elemeztük.

Eredmények: A vizsgált periódusban 406 veseátültetés történt, melyből 24,4\% (n = 99) vesetranszplantáltnál alakult ki intervenciós (sebészeti, radiológiai, urológiai) szövődmény. A betegek átlagéletkora 49,5 $\pm 13,7$ év, 60,8\% férfi volt. A kumulatív mortalitás 10,1\% volt. Grade 4-es szövődmény a betegek 6,9\%-ánál (n=28), Grade 3-as a 6,7\%ánál $(\mathrm{n}=27)$, Grade 2 -es a 3\%-ánál $(\mathrm{n}=12)$, Grade 1 -es a $7,9 \%$-ánál $(\mathrm{n}=32)$ jelentkezett. A veseátültetés után 20,4\%-ban ( $\mathrm{n}=83)$ alakult ki késón induló graftfunkció.

Következtetés: A legenyhébb kategóriába (Grade 1.) került a legtöbb beteg, a szövődmények jelentős része sebészi, intervenciós radiológiai és urológiai közremúködéssel megoldható volt. Az ureteranastomosisok mütéti technikája és a releváns szövődmények kialakulása között nincs szignifikáns összefüggés. Megfelelő és időben alkalmazott korrekciós kezelés mellett a graft- és betegtúlélést nem rontja szignifikánsan az enyhe és középsúlyos (Grade 1-3.) szövődmények kialakulása.

Orv Hetil. 2021; 162(26): 1038-1051.
\end{abstract}

Kulcsszavak: veseátültetés, sebészeti szövődmények, Clavien-beosztás, ureteranastomosis

\section{Surgical complications after kidney transplantation based on the Clavien classification, especially with regard to the types of ureteral anastomoses}

Introduction: Complications associated with postoperative intervention may affect graft and patient survival after kidney transplantation. Monitoring the effectiveness of surgery is an important aspect. Ureter anastomosis can be the pivot of kidney transplant, the same as vascular anastomosis, so efficiency of the surgical technique is important to follow up. 
Objective and method: We retrospectively examined kidney transplants performed between 2010 and 2020 at the Department of Surgery of the University of Debrecen. Data were analyzed by the SPSS statistical program. We aimed to investigate surgical complications, which were systematized based on the modified Clavien classification. In one patient, the most severe complication was used as the basis for the schedule. The minimum follow-up time was 1 year. Results: 406 kidney transplants were performed in the examined period, of which $24.4 \%(\mathrm{n}=99)$ developed renal transplant complications (surgical, radiological, urological). The mean age of the patients was $49.5 \pm 13.7$ years, and $60.8 \%$ were male. The cumulative mortality was $10.1 \%$. Grade 4 complication developed in $6.9 \%(n=28)$ of the recipients, Grade 3 in $6.7 \%(n=27)$, Grade 2 in $3 \%(n=12)$, and Grade 1 in $7.9 \%(n=32) .20 .4 \%$ of the recipients had delayed graft function.

Conclusion: The Grade 1 group had the biggest case number, so a significant part of the complications could be solved with the help of interventional radiology and urologists. There is no significant association between the surgical technique of ureteral anastomoses and the development of related complications. With appropriate therapy, graft and patient survival are not significantly impaired by the development of Grade 1-3 complications.

Keywords: kidney transplantation, surgical complications, Clavien classification, ureteral anastomosis

Illésy L, Fedor R, Kovács DÁ, Kanyári Zs, Zádori G, Szőllősi GJ, Kovács M, Flaskó T, Tóth J, Veisz R, Belán I, Nemes B. [Surgical complications after kidney transplantation based on the Clavien classification, especially with regard to the types of ureteral anastomoses]. Orv Hetil. 2021; 162(26): 1038-1051.

(Beérkezett: 2021. április 8.; elfogadva: 2021. május 11.)

\section{Rövidítések}

ATG = antithymocyta-globulin; AV = arteriovenosus; $\mathrm{BKV}=$ polyomavirus $\mathrm{BK} ; \mathrm{BMI}=($ body mass index $)$ testtömegindex; $\mathrm{CAPD}=($ continuous ambulatory peritoneal dialysis $)$ folyamatos ambuláns peritonealis dialízis; CIT $=($ cold ischemic time $)$ hidegischaemiás idő; $\mathrm{CT}=$ (computed tomography) számítógépes tomográfia; $\mathrm{DGF}=$ (delayed graft function $)$ későn induló graftfunkció; $\mathrm{DJ}=$ dupla J-katéter; $\mathrm{ECD}=($ extended criteria donation) kiterjesztett kritériumú donáció; ESRD = (end-stage renal disease) végstádiumú veseelégtelenség; HLA = humán leukocytaantigén; LMWH = (low-molecular-weight heparin $)$ kis molekulatömegű heparin; $\mathrm{MMF}=$ mikofenolát-mofetil; NPWT $=$ (negative-pressure wound therapy) negatív nyomású sebkezelés; $\mathrm{NS}=$ nephrostoma; $\mathrm{PCR}=$ (polymerase chain reaction) polimeráz-láncreakció; PDS = polidioxanon; PTA = percutan transluminalis angioplastica; $\mathrm{TAC}=$ takrolimusz; UAcomp = ureteranastomosis szövődménye; UNS = ureteroneostomia; UTI = (urinary tract infection) húgyúti fertőzés; $\mathrm{UU}=$ ureteroureterostomia

A végstádiumú veseelégtelenség (ESRD) ellátására alapvetôen két kezelési irány létezik: a dialízis (ezen belül a folyamatos ambuláns peritonealis dialízis [CAPD] vagy a gépi múvesekezelés), valamint a veseátültetés. A veseátültetés jobb életminőséget biztosíthat a betegek számára, mint a hemodialízis vagy akár a CAPD [1]. A mútét kimenetelének tanulmányozása a saját tevékenységünk minőség-ellenőrzésén túl a betegek felé történő átlátható kommunikációt is segíti. Illés és mtsai tanulmánya alapján az ESRD-vel küzdő betegek transzplantációs hajlandóságát erősíti az orvos-beteg bizalmi kapcsolat kiépítése, ami javítja a betegek hozzáállását a szervátültetéshez. Pontos információk birtokában centrumunk munkatársai megnyugtatóan tudnak kommunikálni a veseátültetésről. Ennek hiányában teret nyerhetnek a hiedelmek, félelmek, melyek a betegek negatív attitúdjéhez vezethetnek [2]. Természetesen a minőségelemzés másik fontos következménye a saját klinikai gyakorlat folyamatos monitorozása, fejlesztése, az esetleges hibák javítása, és nem utolsósorban a szakmai (de a szervátültetés szempontjából mégis laikus) közösség felé releváns és idézhető adatok szolgáltatása. A veseátültetést követően kialakult szövődményeket etiológiájuk alapján négy csoportba oszthatjuk: immunológiai, fertőzéses, cardiovascularis vagy műtéttechnikai szövődmények. A jelen tanulmányban az 1994-ben közölt májátültetés monitorozására megalkotott módosított Clavien-beosztást [3] alapul véve rendszereztük a veseátültetéssel összefüggő, intervenciót igénylő szövődményeket centrumunk anyagán, különös tekintettel az ureteranastomosisokkal kapcsolatos komplikációkra.

\section{Célkitüzés}

Célkitüzésünk volt a vesetranszplantáció sebészeti szövődményeinek rendszerezésével a debreceni centrumban 2013 óta szisztematikusan épített, egységes minőségbiztosítási szemlélet további elősegítése, összefüggések keresése az egyes mútéttechnikák és a szövődmények között, illetve azok hatásának vizsgálata a beteg- és grafttúlélésre, végül saját gyakorlatunk más tanulságainak levonása, szükség esetén módosítása, fejlesztése.

Klinikánkon a veseátültetési program 1991-ben indult el, dr. Asztalos László fóorvos vezetésével. 1991 és 2013 között a veseátültetési gyakorlatban a donoruretert szinte minden esetben a húgyhólyagba szájaztatták a Röhl -Ziegler-technikával [4], rendszerint epicystostoma segítségével. Magyarország 2013-ban csatlakozott az Eurotransplanthoz, mely évben Klinikánkon más területeken is 
szakmai paradigmaváltás történt. Ez többek között érintette az indukciós immunszuppressziós kezelés bevezetését, illetve ekkortól kezdtük alkalmazni az ureteroureterostomia (UU) típusú ureteranastomosist, melyet kezdetben válogatott esetekben, majd protokoll szerint minden esetben dupla J (DJ)-katéter-sínezés mellett végeztünk. Adatgyưjjtésünk során többek között arra is kíváncsiak voltunk, hogy milyen arányban jelenik meg anastomosiselégtelenség a két ureteranastomosis-típus esetén. A közlések alapján megoszlanak a vélemények az ureterneoimplantáció technikájáról. Számos mütéttechnikai lehetőség létezik, mellyel a donoruretert a recipiens-húgyhólyaggal vagy -ureterrel lehet egyesíteni. Buttigieg és mtsai veseátültetés után végzett vizsgálata alapján az urológiai szövődmények a tapasztalat felhalmozódása mellett is csökkennek. Az 1970 és 1990 között mért csoportban az előfordulási gyakoriság 4,2-14,1\% volt, majd az újabb beszámolók szerint 1990 és 2000 között ez az arány 3,76,0\%-ra csökkent [5]. Az ureterrel kapcsolatos szövődményeket érdemes a mütéti beavatkozásból adódó valamenynyi egyéb lehetséges sebészi komplikáció kontextusában vizsgálni, ezért a jelen közlemény a veseátültetés szempontjait figyelembe vevő, magunk által módosított Clavien-beosztás szerint az egyéb lehetséges negatív következményeket és azok súlyosságát is rendszerezi.

\section{Módszer}

Retrospektív adatfeldolgozással vizsgáltuk a Debreceni Egyetem Klinikai Központjának Sebészeti Klinikáján a 2010. január 1. és 2019. december 31. között végzett veseátültetéseket. 10 év alatt 406 veseátültetést végeztünk. Az utánkövetés minden esetben legalább 1 év volt, mely időszakban a posztoperatív korai és késői szövődmények is vizsgálhatók voltak. 5 éves valós túlélést (2015. 12. 31. előtt transzplantáltak) 219 mütéti eset után tudtunk számolni, kumulatív túlélést természetesen az egész vizsgált populáción. Kizárási kritérium nem volt, nem zártuk ki az élődonor-veseátültetéseket sem. A szövődmények felmérése a Klinika betegdokumentációs adatbázisában (e-MedSolution) felkereshető adatok elemzésével történt. A statisztikai vizsgálatokat az SPSS Statistics 27.0 program (IBM, Armonk, NY, Amerikai Egyesült Államok) segítségével végeztük. A folyamatos változókat kétmintás T-próbával, Levene-teszttel, valamint Kruskal-Wallis-próbával, míg a karakterisztikus változókat khi-négyzet-próbával elemeztük, 95\%-os konfidenciaintervallummal dolgozva. A túlélési adatokat Kaplan-Meier-görbén szemléltettük, p-értéket ebben az esetben log-rank teszttel számoltunk. Szignifikanciaszintnek azt tekintettük, ha $\mathrm{p}<0,05$ volt.

\section{Clavien-beosztás}

Clavien és mtsai a májátültetéssel kapcsolatban definiálták az általunk is alapul vett klasszifikációt, saját korábbi szövődménybeosztásuk alapján. Ennek lényege, hogy a májátültetés után kialakuló szövődményeket (primer diszfunkció, rejekció, infekció, vérzés, veseelégtelenség, epeúti probléma, diabetes, elhízás, hyperlipidaemia) a beavatkozások súlyossági foka szerint rendezik csoportokba, ezzel komplex beosztást hozva létre. Az enyhe (Grade 1.) csoportba a könnyen, intervenció nélkül kezelhető szövődmények tartoznak, melyek életet nem veszélyeztetnek, gyógyszeres kezelésre gyógyulnak, ágy mellett kezelhetők, vérzés esetén $\leq 3$ egység vörösvértestkoncentrátum adása szükséges, az intenzív osztályos bennfekvés nem nyúlik 5 napon túl, és az összes kórházi bennfekvési idő 4 hét alatt marad. Középsúlyos (Grade 2.) kategóriába sorolják az olyan szövődményeket, melyek 5 napon túli intenzív osztályos ellátást vagy 4 héten túli kórházi bennfekvést igényelnek, de nem okoznak tartós egészségkárosodást. Ezen belül Grade 2 a gyógyszeres kezelést igénylő szövődmény vagy 3 egység vörösvértest-koncentrátum feletti transzfúziós igény. A Grade 2b csoportba kerülnek azok a szövődmények, amelyek miatt invazív intervenció válik szükségessé, a beteg újra intenzív osztályra kerül, vagy 5 napnál tovább igényel intenzív ellátást, de nem okoznak maradandó egészségkárosodást. A súlyos (Grade 3.) csoportba kerülnek azok a szövődmények, amelyek maradandó egészségkárosodást okoznak, illetve a de novo malignus tumorok (kivéve a squamosus és basocellularis bőrdaganatokat). A csoporton belül a Grade 3a csoportba kerültek azok a szövődmények, amelyek kis eséllyel okoztak graftvesztést/ halált, a Grade 3 b csoportba pedig azok, amelyek esetén szignifikáns esély volt a graftvesztésre vagy a beteg elvesztésére. A rendkívül súlyos (Grade 4.) csoportba kerültek azok a szövődmények, melyek retranszplantációhoz (Grade 4a), illetve a beteg elvesztéséhez (Grade 4b) vezettek [3]. Ezt a Clavien-féle beosztást alapul véve hoztunk létre egy, a veseátültetésre - és ezen belül is a mütéttechnikai szövődményekre - alkalmazható egyszerüsített beosztást, mely a mütétet követően kialakult és intervenciós beavatkozást igénylő szövődményeket rendszerezi; ez segíthet a veseátültetéssel foglalkozó centrumok eredményeinek részletesebb összehasonlításában.

Minden, intervenciót (radiológiai, urológiai, sebészeti) igénylő szövődményt összegyújtöttünk, amely a veseátültetéssel volt kapcsolatos. 1 betegnél elvileg több különböző szövődmény is kialakulhatott, illetve egy adott szövődmény több alkalommal, különböző súlyosságban. $\mathrm{Az}$ adott szövődmény esetén mindig a legsúlyosabbat vettük figyelembe a Clavien-féle besorolásnál. A besorolás módját az 1 . táblázat szemlélteti. A beosztás segített abban, hogy az adott szövődményt egységesen tudjuk összehasonlítani mások eredményeivel. Az osztályozás csak a mütéti beavatkozással kapcsolatba hozható sebészeti szövődményeket tartalmazza. Az egyéb, spontán gyógyuló vagy belgyógyászati, immunológiai és más, gyógyszeres kezelést igénylő szövődményeket (hypertonia, diabetes, rejekció) a jelen tanulmányban nem részleteztük, ahogy az egyéb mútéteket (például mellékpajzs- 
1. táblázat |A veseátültetést követő sebészeti, urológiai, radiológiai intervenciót igénylő szövődmények csoportosítása a Clavien-beosztást alapul véve

\begin{tabular}{|c|c|c|}
\hline Beosztás & A szövődmény leírása & Példák \\
\hline Grade 0 . & Nem volt intervenciót igénylő szövődmény & \\
\hline $\begin{array}{l}\text { Grade } 1 . \\
\text { Grade la } \\
\text { Grade } 1 b\end{array}$ & $\begin{array}{l}\text { a) A graftmúködést nem veszélyeztető, mútétet nem igénylö, } \\
\text { de sebmegnyitással járó szövődmények } \\
\text { b) A graftot veszélyeztető radiológiai vagy endoszkópos } \\
\text { (urológiai) intervenciót igénylő szövődmények }\end{array}$ & $\begin{array}{l}\text { a) Sebfertőzés, seroma } \\
\text { b) Graft körüli folyadék, vizeletelfolyási akadály } \\
\text { (ureterobstructio, stenosis) }\end{array}$ \\
\hline Grade 2. & Reoperáció graftot nem veszélyeztető szövődmény miatt & $\begin{array}{l}\text { Lymphokele, hegsérv, hasfalat is érintő sebszétválás, } \\
\text { NPWT-igényú sebgennyedés }\end{array}$ \\
\hline $\begin{array}{l}\text { Grade } 3 . \\
\text { Grade } 3 \mathrm{a} \\
\text { Grade } 3 \mathrm{~b}\end{array}$ & $\begin{array}{l}\text { Reoperáció graftot veszélyeztető szövődmény miatt } \\
\text { a) Ureteranastomosis szövődménye miatt mûtét } \\
\text { b) Vérzés, thrombosis miatt mûtét }\end{array}$ & $\begin{array}{l}\text { a) Ureterstenosis, -necrosis, vizeletcsorgás } \\
\text { b) Diffúz vérzés, lumenes vérzés, artériás/vénás thrombosis }\end{array}$ \\
\hline Grade 4. & $\begin{array}{l}\text { Olyan posztoperatív szövődmény, melynek következménye } \\
\text { graftectomia }\end{array}$ & $\begin{array}{l}\text { Ureteranastomosis-elégtelenség, uralhatatlan vérzés, } \\
\text { thrombosis, szeptikus góc, immunológiai ok }\end{array}$ \\
\hline
\end{tabular}

NPWT = negatív nyomású sebkezelés

mirigy, Tenckhoff-katéter vagy CAPD-katéter eltávolítása, prosztatamútét stb.), egyéb intervenciókat (például cardialis intervenció) és azok szövődményeit sem. A Grade 0. csoportba a szövődménymentes esetek tartoznak. A Grade 1-es csoportba a graftmúködést nem veszélyeztető szövődmények kerültek, melyeket ágy mellett sebmegnyitással (Grade la) vagy radiológiai, urológiai (nem mútétes) intervencióval meg lehetett oldani (Grade 1b). A Grade 2-es csoportba kerültek azok a betegek, akiknél a legsúlyosabb szövődmény bár a graft múködését nem veszélyeztette, reoperációt igényelt (lymphokele, hegsérv, sebszétválás, komolyabb sebgyógyulási zavarok). A Grade 3-as kategóriába kerültek azok a betegek, akiknél a szövődmény közvetlenül veszélyeztette a graft múködését: a Grade 3a alcsoportba az ureteranastomosis szövődményei (ureterstenosis, -necrosis, vizeletcsorgás) miatt végzett reoperációk, a Grade 3b alcsoportba pedig a vascularis szövődmények (vérzés, thrombosis) miatt végzett reoperációk kerültek.

A szövődmények egy jelentős részét a veseátültetés után kialakuló bakteriális fertőzések jelentik, melyek között kiemelkedő a húgyúti fertőzések (UTI-k) száma. Ezek közül a járóbeteg-ellátás keretében megjelenő esetek jelentős része ambulánsan kezelhető. A korai posztoperatív időszakban megjelenő esetek ritkák, és számos esetben műtéti, sebésztechnikai hibák következményei ezért a jelen tanulmányban az UTI tekintetében csak a posztoperatív korai időszak (<30 nap) fertőzését detektáltuk, és azokat is elsősorban a technikai jellegü elemzés részeként, mint következményt. A graftectomiák kisebb része a késői posztoperatív időszakba esik ugyan, de egyes esetekben indikációjuk közvetlenül köthető volt valamilyen mütéttechnikai szövődményhez (például az ureteranastomosis elégtelensége), más esetekben a graft mint fertőzéses góc szerepelt, amelyet szintén sebészi szövődménynek értékeltünk. Emiatt Grade 4-es szövődménynek tekintettünk minden olyan esetet, amelyben végül graftectomiára került sor.

\section{Perioperatín stratégia}

A veseátültetést Debrecenben protokoll szerinti preoperatív kivizsgálást követően, meghatározott rend szerint végezzük minden alkalommal. A veseátültetések előtt minden esetben, a posztoperatív tehermentesítés céljából, Foley-katétert helyezünk be. A szokásos mütéti behatolás a Gibson szerinti laterális, ívelt metszés, amelynek során feltárjuk a retroperitoneumot. Az érvarratok tekintetében a donorvese vénáját rendszerint a recipiens vena (v.) iliaca externára, az artériát pedig az arteria (a.) iliaca externára, ritkábban az a. communisra varrjuk, mindkét esetben 5/0-s Prolene tovafutó 'end-to-side' (vég az oldalhoz ) varrattal. Amennyiben azonos oldali fossa iliacába ültetjük a vesét (bal a bal oldalra vagy jobb a jobb oldalra), az esetek többségében fordított állásban ültetjük be ('upside down'), a fentiek miatt. Kivételt képez, ha a donorvese erei elég hosszúak ahhoz, hogy azonos oldali, de egyenes állásban történő implantáció mellett is könnyen kivitelezhető legyen az anastomosis. Az ureter hosszát a mútéti helyzet ismeretében határozzuk meg, illetve annak alapján, hogy a vérellátás intakt maradjon, azaz legyen „mesoureter”. Az UU-anastomosis esetén a donorureter végén ún. „kobrafej” formát alakítunk ki, hosszanti metszéssel. A 'kinking' (megtörés) és a tengelyirányú forgás prevenciója mellett a donoruretervéget adaptáljuk a recipiensureterhez, melyen szintén hosszanti metszést ejtünk. A recipiens ureter-húgyhólyag-urethra rendszer átjárhatóságáról a hólyagon ejtett metszésen átvezetett tápszondán keresztül injektált hígított jódoldat segítségével győződünk meg. A varrat két irányöltés között készül, 'end-to-side', tovafutó technikával, 5/0-s Maxon vagy PDS-fonallal. A rendszerbe a második varratsor (elülső fal) elkészítése előtt megfelelő méretû DJ-sínt vezetünk. A sínnek a donorvese-pyelonba érkezése jól ellenőrizhető a mútéti feltárás oldalán: a hólyagban levő jódoldat visszacsorgása sokszor indikátor arra nézve, hogy a sín megérkezett a hólyagba. Ureteroneostomia (UNS) esetén a húgyhólyagot a hólyagkatéter 
felől hígított metilénkékkel töltjük fel, a reperfúzió után. A mütéti terület felől preparálva azonosítjuk a hólyagot (ha nem egyértelmú, akkor punkcióval). Először a symphysis felett percutan szettel sínt vezetünk a hólyagba, amelyet ezután a mútéti terület felől két irányöltés között megnyitunk. A sínt felvezetjük a donorureteren át a donorvese-pyelonig, majd két irányöltés között elkészítjük az anastomosist. Ez 5/0-s PDS-fonallal készül, tovafutó technikával. A varratsor tunnelizálását az esetek 90\%-ában elvégezzük lege artis két csomós öltéssel, a hólyagfal „laza” összehúzásával. A donormútét során a jobb oldali vese - a kivételi technika miatt - a v. cava inferior egy szakaszával együtt kerül eltávolításra. Az anatómiai okok miatt rövid renalis vénát a v. cava inferior szakasz „csövesítésével” hosszabbítjuk meg. A v. renalishoz tartozó v. cava inferior szakasz két végének lezárása után a bal oldali vesevéna beszájadzásának helye lesz az anastomosis helye. A vénás varratot két irányöltés között végezzük el tovafutó formában. Az artériás anastomosist lehet ugyanígy, de az esetek döntő többségében 2013 óta egy irányöltés körül, tovafutó varrattal. Minden esetben heparinos öblítés történik, de a betegnek szisztémás heparint nem adunk (az uraemia okozta vérzékenység miatt). Lényeges elem, hogy a mütét végén a vesét úgy helyezzük el a retroperitoneumban, hogy megtöretés ne alakuljon ki. Kétség esetén a mútét végén mini-Dopplervizsgálattal ellenőrizzük a keringést. Az uretersínt a posztoperatív 12-14. nap környékén távolítjuk el, még a kórházi bennfekvés alatt, miután a spontán vizelet menynyisége meghaladja az epicystostomán ürített mennyiséget. Az UU-anastomosis esetén használt, intraoperatíven felhelyezett DJ-sínt urológusok távolítják el a posztoperatív 6-8. héten. Minden esetben mütéti drént hagyunk a beültetett vese mellett, jelentős adipositas esetén a subcutan régiót is drénnel látjuk el. Antibiotikumprofilaxis céljából cefotaxim az elsőként választandó szer, melyet egészen az intravénásan alkalmazott metilprednizolonterápia per os váltásáig alkalmazunk. Pneumocystis carinii fertőzés megelőzésére szulfonamid/trimetoprim profilaxist alkalmazunk, alternáló napokon adva a posztoperatív 6. hónapig. Cytomegalovirus-fertőzés megelőzésére orális valganciklovirt adunk 3 hónapig, ugyancsak alternáló napokon. Az alap-immunszuppresszió takrolimusz (TAC), mikofenolát-mofetil (MMF) és szteroid kombinációját jelenti. Indukciós kezelést 2013 óta az esetek 99\%-ában alkalmazunk (a kivételt a 6 HLA-egyezés jelenti, jó hidegischaemiás idő [CIT] mellett). Ez bazilixi$\mathrm{mab}(20 \mathrm{mg}$ iv. a 0 . és 4 . posztoperatív napon) vagy antithymocyta-globulin (ATG; 0,8-1,25 mg/ttkg iv. a 0-3. egymás utáni napokon) adását jelenti. A vizsgált időszakban 1 esetben adtunk daklizumabot.

A betegek a mütét befejezése után 4-6 órával megkapják az első LMWH-adagot preventív dózisban. A vese keringését a posztoperatív idószakban minden olyan esetben Doppler-vizsgálattal ellenőrizzük, amelyben a mütéti helyzet ezt eleve indokolja (többes, gracilis vagy rekonstruált artéria, esetleg mütét alatt újra elkészített varrat), továbbá ha a mútét előtt anuriás betegnél a de novo diuresis nem indul meg 4-6 óra alatt, illetve ha a megindult diuresis csökken vagy megszúnik, valamint ha a betegnél szubjektív panaszok (fájdalom) lépnek fel.

A transzplantáló sebészkollégák felé elvárás a transzplantációs osztályon levő készülék segítségével a sürgős (azonnali), ágy melletti Doppler elvégzése és a keringés meglétének értékelése addig is, amíg a beteget radiológus megvizsgálja. Amennyiben ez is kétséges Dopplereredménnyel zárul, CT-angiográfia történik (majd hemodialízis a kontrasztanyag-terhelés miatt), és ennek ismeretében döntünk a további teendőkről. A korai posztoperatív időszakban (0-7 nap), és ha a feltételezett keringészavar után rövid idő telt el, azonnali reoperációt végzünk. Azokban az esetekben, amelyekben a keringészavar miatt készült CT-vizsgálat során stenosis merül fel, illetve továbbra sem egyértelmü a diagnózis, de a thrombosis kizárható, a probléma és a mútét után eltelt időtartam függvényében egyre inkább intervencionális radiológiai megoldást választunk.

Klinikánkon protokoll-vesebiopsziát nem végzünk, a kérdéses esetekben percutan CT-vagy ultrahangvezérelt biopszia történik. A beavatkozás másnapján Dopplerkontroll történik arteriovenosus (AV) sönt vagy egyéb eltérés kizárására. Iatrogén AV sönt kialakulása esetén csak abban az esetben avatkozunk be, ha az AV sönt klinikai tünetekkel jár. Az AV söntök egy része spontán záródik, így 2-3 hét megfigyelési időt tartunk megfelelőnek. Amennyiben ez nem történik meg, és/vagy a 'steal' effektus (vérelszívás) miatt ez a vesemúködést is érinti, akkor az AV söntnek percutan angiográfia során elvégzett intervencionális ('coil') embolisatiója történik.

\section{Eredmények}

Megbeszélésünk elején szeretnénk hangsúlyozni, hogy a sebészeti szövődmények nem a sebész hibáját (szövődményét) jelentik, hanem minden olyan komplikációt, amely összefüggésbe hozható a mútéti vagy más intervenciós beavatkozás technikai részével, illetve sebészi vagy intervencionális módszerrel oldható meg. Erre egyegy példa a mütéti hegben kialakult sérv, illetve a posztoperatív időszakban végzett percutan vesebiopszia után kialakult AV fistula. Az eredmények elemzése során nem véletlenül nem használjuk a hiba fogalmát, mivel e szövődmények aránya a kifejezetten sérülékeny és számos egyéb társbetegséggel bíró uraemiás betegcsoport esetén a leggondosabb és legszakszerúbb eljárás, kezelés mellett sem csökkenthető nullára.

A sebészeti, radiológiai, urológiai intervenciót igénylő szövődményeknek, az alkalmazott intervenciótípusoknak az eloszlását az általunk módosított Clavien-beosztás függvényében a 2. táblázat mutatja be. Mivel a graftectomia kivételével minden szövődmény potenciálisan előfordulhat többször is egy betegnél, és számos esetben ez így is történt, a beavatkozások számának összege nem egyenlő a stádiumbeosztásnál jelzett esetszámmal, hiszen 
2. táblázat |A veseátültetést követő szövődmények, intervenciók eloszlása az általunk módosított Clavien-beosztás szerint

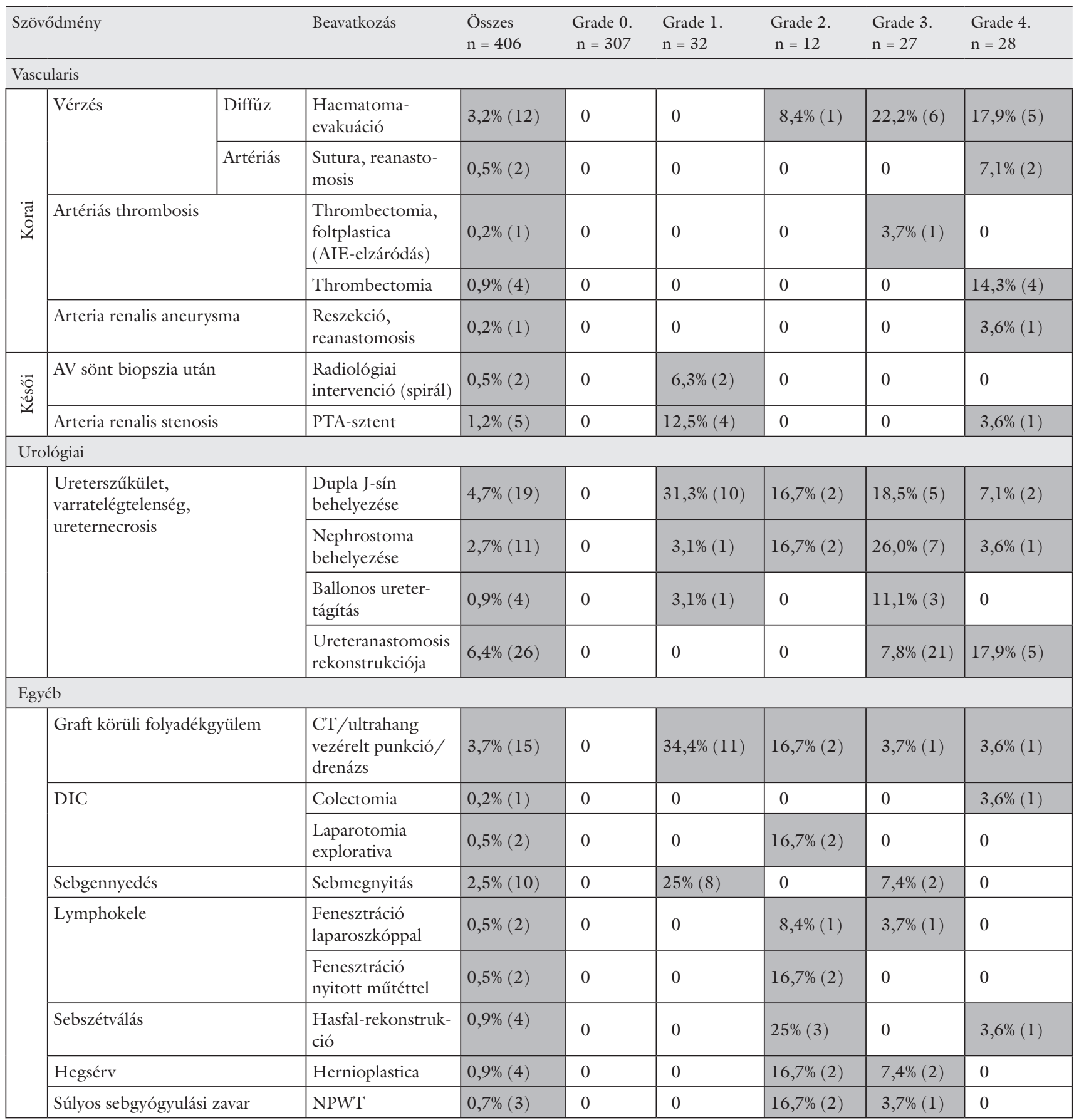

$\mathrm{AIE}=$ arteria iliaca externa $\mathrm{AV}=$ arteriovenosus; $\mathrm{CT}$ = számítógépes tomográfia NPWT = negatív nyomású sebkezelés; PTA = percutan transluminalis angioplastica

azt a recipiensekre vonatkoztatva adtuk meg, betegenként a legsúlyosabb szövődménnyel számolva. A vascularis szövődmények többsége Grade 3-as és graftvesztéssel járó Grade 4-es szövődménnyel jár. Az urológiai szövődmények jelentős része mútét nélkül megoldható. A posztoperatív időszak a recipiensek $75,6 \%$-ánál $(\mathrm{n}=307)$ volt teljesen szövődménymentes (Grade 0.). Az urológiai szövődményeket tovább taglaljuk a későbbiekben, melyeket a 4.és 5. táblázat is bemutat, a vascularis eredetú szövődményeket azonban egyedül a 2. táblázat részletezi, így errôl itt ejtünk szót bővebben. Vesebiopszia után kialakuló AV fistula miatt 2 esetben volt szükség radiológiai intervencióra, egyéb szövődményt egyik esetben sem észleltünk, így ők a Grade l-es kategóriába kerültek. Allograftbiopsziát nem végzünk protokollszerúen, így az ezzel kapcsolatos szövődmények arányának nincs klinikai relevanciája. A legáltalánosabb szövődményként említhető posztoperatív vérzés miatt haematomaevakuációra 
12 esetben volt szükség, melyek közül egyet fentebb említettünk. A mütétre akkor került sor, ha a hátterében aktív vérzést feltételeztünk, a haematoma nyomási tüneteket okozott, mérete növekedett, vagy gócként merült fel. 6 betegnél volt önálló szövődmény a reoperációt igénylő diffúz vérzés, 5 esetben haematomaevakuációt követően végül graftectomia történt (Grade 4.). Egy esetben CT-vezérelt drenázs ürítette le a haematomát, mely után vérzés nem ismétlődött (Grade 1.). 2 betegnél lumenes vérzés miatt reoperációt végeztünk, mely minden esetben graftvesztéssel járt (Grade 4.). Egy esetben v. iliaca externa sérülés miatt végeztünk sürgős mútétet, a másik esetben a mútét után 8 nappal kialakult akut vérzés hátterében az artériás anastomosis elégtelenségét igazoltuk: itt az artéria környezete gyulladt volt, falának részleges elhalását feltehetően (gombás) szeptikus folyamat okozta, ebben az esetben is graftectomiára kényszerültünk. 5 betegnél artériás thrombosis miatt reoperációt végeztünk, melyek közül l esetben volt lehetséges a graft megmentése. 1 betegünknél halmozottan léptek fel szövődmények. A mútét után először vizeletcsorgás miatt reoperációt végeztünk (Grade 3a), majd a. renalis szúkü̈let miatt artériás PTA és sztent beültetése történt. Ezt követően növekvő a. renalis aneurysma miatt ennek reszekciójára került sor, reanastomosis készült. Később haematomaevakuáció vált szükségessé, végül az anastomosis elégtelensége és rekonstrukciós lehetőségek hiánya miatt graftectomiára kényszerültünk (Grade 4.). 5 betegnél a graft artériájának szúküulete miatt PTA történt, közülük 4 betegnél más szövődményt nem észleltünk (Grade 1.).
A vascularis és az uretert érintő szövődmények eltérő eloszlást mutatnak az egyes csoportokban. Míg a vascularisak inkább a korai időszakban, akutan okozhatnak graftvesztést, az urológiaiak korrekció hiányában a késői graftvesztés okai lehetnek. A Grade l-es csoportban a későn kialakuló és az életet/vesét nem veszélyeztető, tervezetten ellátható vascularis szövődmények domináltak (stenosis), a Grade 3-as és 4-es csoportban pedig a korai (közvetlen posztoperatív) időszakban észlelt, azonnali beavatkozási igénylő, a vesét veszélyeztető komplikációk (vérzés, thrombosis). Látható, hogy az enyhe (Grade 1.) mellett a mérsékelten súlyos (Grade 2.) csoportra általánosságban inkább az uretert érintő szövődmények voltak jellemzőek, a vascularisak kevésbé. Ezen belül a Grade 1-es csoportban a veseátültetés után közvetlenül észlelt vizeletcsorgás miatt felhelyezett uretersín, míg a Grade 3-as csoportban a késői szövődményként észlelt és tervezetten reoperálandó ureterstenosis volt jellemző.

Enyhe (Grade 1.) szövődmény 32 (7,9\%) beteg esetében alakult ki, ezek közül a leggyakoribb a mútéti beavatkozást nem igénylő sebfertózés, sebszétválás volt ( $\mathrm{n}=17)$. A legtöbb irodalmi közlés ezeket a szövődményeket nem említi, mert nincsenek kihatással sem a beteg későbbi, hosszú távú életminőségére, sem a közvetlen posztoperatív időszak elhúzódására. Közepes súlyosságú szövődményt (Grade 2.) a recipiensek 3,0\%-ánál $(\mathrm{n}=12)$ észleltünk. Súlyos, de a beültetett vesét vagy a beteg életét nem veszélyeztető (Grade 3.) olyan szövődmény, amely ismételt mútéti vagy intervenciós beavatkozást igényelt, és ismételt vagy megnyújtott kórházi bennfek-

3. táblázat | Egyes recipiensparaméterek összefüggése a veseátültetést követő szövődményekkel a Clavien-beosztás szerint

\begin{tabular}{|c|c|c|c|c|c|c|}
\hline & $\begin{array}{c}\text { Grade } 0 . \\
75,6 \% \\
(\mathrm{n}=307)\end{array}$ & $\begin{array}{c}\text { Grade } 1 . \\
7,9 \% \\
(\mathrm{n}=32)\end{array}$ & $\begin{array}{c}\text { Grade } 2 \text {. } \\
3,0 \% \\
(\mathrm{n}=12)\end{array}$ & $\begin{array}{c}\text { Grade } 3 . \\
6,7 \% \\
(n=27)\end{array}$ & $\begin{array}{c}\text { Grade } 4 . \\
6,9 \% \\
(\mathrm{n}=28)\end{array}$ & $\mathrm{p}$ \\
\hline Életkor (átlagév) & $48,8 \pm 13,6$ & $54,8 \pm 11,1$ & $59,3 \pm 11,6$ & $51,5 \pm 12,8$ & $44,9 \pm 15,6$ & $<0,05$ \\
\hline Gender (férfi) & $189(62 \%)$ & $23(72 \%)$ & $7(58 \%)$ & $16(59 \%)$ & $12(49 \%)$ & NS \\
\hline Testtömegindex & $26,0 \pm 4,2$ & $27,0 \pm 5,0$ & $28,3 \pm 6,0$ & $25,3 \pm 5,3$ & $24,9 \pm 4,6$ & NS \\
\hline Diabetes mellitus & $49(16 \%)$ & $9(28 \%)$ & $3(25 \%)$ & $8(30 \%)$ & $3(11 \%)$ & NS \\
\hline Predialitikus & $23(7,5 \%)$ & $2(6 \%)$ & $2(17 \%)$ & $1(4 \%)$ & $3(11 \%)$ & NS \\
\hline Indukciós terápia & $203(66 \%)$ & $30(94 \%)$ & $10(83 \%)$ & $16(59 \%)$ & $17(61 \%)$ & $<0,05$ \\
\hline ATG & $152(49,5 \%)$ & $24(75 \%)$ & $8(67 \%)$ & $13(48 \%)$ & $12(43 \%)$ & NS \\
\hline BAS & $50(16 \%)$ & $6(19 \%)$ & $2(17 \%)$ & $3(11 \%)$ & $5(18 \%)$ & NS \\
\hline DAC & $0,3 \%(1)$ & 0 & 0 & 0 & 0 & NS \\
\hline Szteroid & $305(99 \%)$ & $32(100 \%)$ & $12(100 \%)$ & $27(100 \%)$ & $26(93 \%)$ & NS \\
\hline TAC & $306(99,7 \%)$ & $32(100 \%)$ & $12(100 \%)$ & $27(100 \%)$ & $25(89 \%)$ & $<0,05$ \\
\hline MMF & $285(93 \%)$ & $30(94 \%)$ & $12(100 \%)$ & $25(93 \%)$ & $21(75 \%)$ & NS \\
\hline Uretersín (DJ/ECS) epicystosstoECS) & $279(91 \%)$ & $29(91 \%)$ & $11(92 \%)$ & $19(70 \%)$ & $23(82 \%)$ & $<0,05$ \\
\hline DGF & $47(15 \%)$ & $8(25 \%)$ & $2(17 \%)$ & $10(37 \%)$ & $16(57 \%)$ & $<0,05$ \\
\hline Húgyúti fertőzés & $70(23 \%)$ & $11(35 \%)$ & $5(52 \%)$ & $6(22 \%)$ & $9(32 \%)$ & NS \\
\hline
\end{tabular}

ATG $=$ antithymocyta-globulin; BAS = baziliximab; DAC = daklizumab; DGF = későn induló graftfunkció; DJ = dupla J-katéter; ECS = epicystostoma; $\mathrm{MMF}=$ mikofenolát-mofetil; $\mathrm{NS}=$ nem szignifikáns; TAC = takrolimusz 
véssel járt, a transzplantáltak 6,7\%-ánál $(\mathrm{n}=27)$ alakult ki. Ezek közül 74,0\% (n = 20) Grade 3a szövődmény volt: 15 esetben vizeletcsorgás, 11 esetben ureterstenosis miatt kellett reoperációt végezni, 9 esetben egyúttal ureternecrosis állt a vizeletcsorgás hátterében, melyet azonban rekonstruálni lehetett. Az esetek felében $(\mathrm{n}=10)$ a mútétet megelőzte urológiai (DJ-sínezés) vagy radiológiai intervenció. Grade $3 \mathrm{~b}$ (vérzés vagy thrombosis miatt reoperáció) a betegek 29,6\%-ánál (n = 8) fordult elö, melyek közül 6 esetben történt kizárólag vascularis szövődmény miatt reoperáció. Ezeket részletezve: 1 esetnél az a. iliaca externa elzáródása miatt történt thrombectomia, foltplasztikával, sikerrel. 5 esetben haematomaevakuációt végeztünk, aktív vérzésforrás nem volt. Többszöri reoperáció a Grade 3-as csoportban 3 betegnél történt. I betegnél fordult elő a Grade 3a csoportban, hogy kétszer kényszerültünk reoperációra: a posztoperatív 20. napon ureternecrosis miatt resutura, majd a 24. napon vizeletcsorgás miatt ismételt mütét történt. Végül jó vesefunkcióval engedtük otthonába a beteget, további intervenciót nem igényelt. 2 esetben Grade 3a és 3b szövődmény együttesen fordult elő, melyek közül az egyik esetben a műtét után 21 nappal végeztünk haematomaeltávolítást, egy ülésben vizeletcsorgás miatt pótöltést helyeztünk be az UNS-varratsornál. A második esetben pedig a posztoperatív 4. napon végeztünk haematomaevakuációt, majd az anastomosis (UNS) szúkülete miatt a posztoperatív 5 . hónapban rekonstrukciót végeztünk (a szűkült rész kimetszése, reUNS).

Grade 4-es súlyosságú, azaz a beültetett vesét veszélyeztető szövődmény 28 betegnél (6,9\%) alakult ki, mely graftectomiát jelentett minden esetben, a mútéttől eltelt idő és a graftectomia indikációjától függetlenül. A graftectomia $67,9 \%$-a $(\mathrm{n}=19)$ akut mútét volt, a többi tervezett. Az akut graftectomiák 63,2\%-át $(\mathrm{n}=12)$ immunológiai eredet gyanúja miatt végeztük, melyek közül l eset szövettannal igazolt hiperakut rejekció volt. $6(21,4 \%)$ esetben végeztünk akut graftectomiát Grade3 szövődmény előzményével, l esetben pedig szeptikus góc miatt.

Összességében elmondható, hogy 6 betegnél kellett életmentő jelleggel reoperációt végezni a beültetéssel összefüggő indikációval, ezen esetek így sebészeti szövődménynek minősíthetők. Tehát a rendkívül súlyos (Grade 4.) csoporton belül mindössze 6 betegnél (1,47\%) volt Grade 4b, azaz életet veszélyeztető szövődmény. Ez elfogadható arány nemzetközi összehasonlításban is.

\section{Graftectomia}

A tervezett graftectomiák közül l esetben a graft visszatérő infekciója, szeptikus góc volta miatt, l esetben pedig az ureteranastomosis elégtelensége miatt, rekonstrukciós lehetőség hiányában kényszerültünk graftectomiára. Korábbi tanulmányunkban, egy szintén 10 éves periódust (2004-2014) vizsgáló elemzésben $(\mathrm{n}=417)$, az allograftnephrectomiák aránya $11,7 \%(\mathrm{n}=49)$ volt.
A leggyakoribb graftectomiaindikációnak a krónikus allograftnephropathiát (51\%) találtuk, a betegek 15\%-ánál artériás szúlkület vagy thrombosis, 6\%-ánál terápiarezisztens akut rejekció, 6\%-ánál pedig nem rekonstruálható ureteranastomosis volt a graftectomiát megelőző vagy azt indokoló szövődmény. A graftectomiák 33,3\%-a akut, kétharmada pedig elektív mútét volt, melyek közül $22 \%$ a posztoperatív korai (<30 nap), 78\% a késői időszakban történt [6]. Egy másik tanulmányunkban, a korábbi dolgozatot tovább bóvítve, 11 év anyaga, 480 veseátültetés alapján 55 betegnél (11\%) vált szükségessé graftectomia [7]. A jelen dolgozatban a Grade 4-es szövődmények aránya $6,9 \%$ : az akutan végzett graftectomiák aránya jelentősen csökkent, az ennek hátterében korábban észlelt artériás thrombosis/stenosis előfordulása szintén. Az elektíven végzett graftectomiák számának csökkenése mögött nem technikai ok jelenik meg. Korábban a nem múködő vesék nagy része rutinszerűen eltávolításra került, a 2013-ban történt paradigmaváltás részeként viszont tervezett graftectomiát csak abban az esetben végzünk, ha a vesegraft gócként igazolható.

A recipiensek demográfiai paramétereit, az alkalmazott immunszuppresszív kezelést, a későn induló graftfunkció (DGF: a veseátültetést követően nem azonnal meginduló vesemúködés, amely legalább 1 múvesekezelést igényel) arányát és az UTI összefüggéseit a Clavienbeosztás függvényében a 3. táblázat ismerteti. A testtömegindex (BMI) és az életkor közötti összefüggéseket a Clavien-beosztás függvényében, Kruskal-Wallis-próbával vizsgáltuk. A betegek életkora és a Clavien-beosztás egyes csoportjai között szignifikáns $(p<0,05)$ összefüggést találtunk, mely szerint a szövődménymentes csoport (Grade 0.) átlagéletkora 48,8 \pm 13,6 év volt, míg az enyhe szövődmények esetén (Grade 1.) 54,8 1 11,1 év, a középsúlyos szövődmények kialakulása esetén (Grade 2.) $59,3 \pm 11,6$ év, a Grade 3. súlyossági fokozat esetén 51,5 $\pm 12,8$ év, és végül a Grade 4-es csoportban 44,9 \pm 15,6 év. A BMI-értékek és a beosztás között nem volt kimutatható szignifikáns kapcsolat $(\mathrm{p}>0,05)$. A karakterisztikus változókat khi-négyzet-próbával elemezve (egyenként a túlélés és a változók között) külön-külön szignifikáns összefüggést találtunk az indukciós immunszuppresszív terápia, a DGF, az uretersín-használat és a Clavien-beosztás között. A vesetranszplantációk után 83 betegnél $(20,4 \%)$ alakult ki DGF. Közülük 47 beteg $(56,6 \%)$ a Grade 0 . csoportba tartozik. Azok között, akiknél a mütét után DGF alakult ki, 16 beteg (a DGF-csoport 19,3\%-a) tartozott az intervenciót igénylő súlyos szövődmények (azaz a Grade 4-es) kategóriába. Úgy találtuk, hogy a magasabb súlyosságú Clavien-kategóriákba sorolható betegek között egyúttal nagyobb arányban fordult elő uretersín használata (egy változóként kezelve - UNS esetén epicystostoma, UU esetén DJ-sín) és indukciós kezelés is. Ez azonban önmagában nem utal ok-okozati kapcsolatra. A magasabb súlyossági fokozatú technikai szövődmények kialakulása nem köthető ugyan minden esetben életkorhoz, azon- 
ban azt tapasztaltuk, hogy a Clavien-beosztás szerinti 3 . és 4. csoportba tartozó betegek idősebbek voltak. Az indukciós kezelést (ezen belül ATG-t) elsősorban alacsonyabb HLA-egyezés, hosszabb CIT, tehát ECD-donorvese (ECD: marginális donor - 60 év feletti, vagy 50-59 év közötti legalább kettő előfordulással a következőkből: hypertonia, szérumkreatinin > $>133 \mathrm{mmol} / 1$ vagy cerebrovascularis halálok) és/vagy idősebb recipiens (Eurotransplant Senior Program) esetén alkalmaztunk. Ezek a betegek esendőbbek, és az erôsebb immunszuppresszió hajlamosít fertőzésre, különösen, ha locus minoris resistentiae is jelen van (például enyhe vizeletcsorgás, stenosis). A beültetett vesék között magasabb arányban volt jelen az a. renalis sclerosisa, illetve a nem kritikus, de jelen lévő parenchymás hegesedés ronthatja a microvascularisatiót. Természetesen ezek nem magyarázzák a konkrét technikai szövődményeket, de a graftvesztéshez vezető negatív spirálban szerepet játszhattak. Tanulmányunk bővítését tervezzük a donoradatok összevetésével, amely a fentiekrôl bővebb információval szolgálhat. Az UTI-k kialakulásának gyakorisága nem korrelált a technikai szövődményeknek a Clavien-beosztás alapján definiált általános súlyosságával.

Az ureteranastomosissal kapcsolatos szövődményekre külön figyelmet fordítottunk. Önálló alcsoportokat alkotva vizsgáltuk, hogy szükséges volt-e intervenció kizárólag ureteranastomosis szövődménye (UAcomp) miatt. A Grade 3-as kategórián belül létrehoztuk a Grade 3a csoportot (UAcomp+ megjelöléssel), amely a mútéti/ intervenciós beavatkozást igénylő ureterszövődményeket jelentette. Az UAcomp-csoportba osztottuk azokat, akiknél nem volt szükség ureteranastomosist érintő intervencióra. Ez a csoport nem egyenlő a Grade 0. csoporttal, mert az UAcomp-kategóriába kizárólag az ureteranastomosissal kapcsolatos szövődmények kerültek. $\mathrm{Az}$ ureteranastomosis szövődményeinek vizsgálatából 1 esetet kizártunk duplex ureter miatt (UU és UNS is készült), így ezzel kapcsolatban 405 volt az esetszám. Az ureteranastomosissal összefüggő szövődményeket a 4 . táblázat szemlélteti. Az UNS-technika esetében jelentösen magasabb volt a posztoperatív szövődmények aránya, de statisztikailag mégsem mutatott szignifikáns különbséget az UU-mütéttechnikához képest. Anastomosiselégtelenség miatti reoperációra a primeren UNSeseteknél kényszerültünk a leggyakrabban. A korai UTI-k több recipiensnél fordultak elő UU-anastomosis mellett, mint UNS után, ez viszont statisztikailag nem bizonyult szignifikánsnak. A jelenséget az UU-technika során alkalmazott DJ-sín átmeneti vizeletrefluxot okozó mellékhatása kielégítően magyarázza. Az 5. táblázatban az ureterszövődménnyel járó esetek után szükséges intervenciók típusait szemléltettük. A vizsgált populációban 39 betegnél $(9,6 \%)$ alakult ki ureterszövődmény (UAcomp+). Közülük 27 esetben (az összes ureterszövődményes 69,2\%-a) volt szükség átmeneti percutan nephrostoma (NS) készítésére, DJ-katéter behelyezésére vagy ballonos tágításra, 26 betegnél $(66,7 \%)$ pedig re-
4. táblázat $\mid$ Az egyes ureteranastomosis-típusok után észlelt szövődmények

\begin{tabular}{lccc}
\hline UAcomp & $\begin{array}{c}\text { UNS } \\
(\mathrm{n}=201)\end{array}$ & $\begin{array}{c}\text { UU } \\
(\mathrm{n}=204)\end{array}$ & $\mathrm{p}$ \\
\hline UAcomp- & $88,1 \%(177)$ & $92,6 \%(189)$ & $\mathrm{NS}$ \\
UAcomp+ & $11,9 \%(24)$ & $7,4 \%(15)$ & \\
Sebészeti & $8,5 \%(17)$ & $4,4 \%(9)$ & $\mathrm{NS}$ \\
Vizeletcsorgás & $5,5 \%(11)$ & $4,4 \%(9)$ & $\mathrm{NS}$ \\
Ureternecrosis & $3,0 \%(6)$ & $2,9 \%(6)$ & $\mathrm{NS}$ \\
Ureterszúkület & $9,0 \%(18)$ & $6,4 \%(13)$ & $\mathrm{NS}$ \\
Húgyúti fertózés & $21,9 \%(44)$ & $28,4 \%(57)$ & $\mathrm{NS}$ \\
\hline
\end{tabular}

Sebészeti: reoperációt igénylő UAcomp

NS = nem szignifikáns; UAcomp = ureteranastomosis szövődménye; $\mathrm{UNS}=$ ureteroneostomia; $\mathrm{UU}=$ ureteroureterostomia

5. táblázat |Az ureteranastomosis-szövődmények intervenciójának eloszlása veseátülttetés után

\begin{tabular}{ll}
\hline Az intervenció típusa & $\mathrm{n}=39$ \\
\hline Nem sebészeti intervenció & $69,2 \%(27)$ \\
Dupla J-sín* & 19 \\
Nephrostoma & 11 \\
Ballonos tágítás & 4 \\
\hline Sebészeti intervenció (reoperáció) & $66,7 \%(26)$ \\
Ureteroneocystostomia & 13 \\
Pótöltés & 4 \\
Ureteroureterostomia & 3 \\
Pyeloneocystostomia & 3 \\
Pyeloureterostomia & 1 \\
Ureteropyelostomia & 1 \\
Ureterotomia, dupla J-sín behelyezése & 1 \\
\hline
\end{tabular}

*Dupla J-sín behelyezés/repozíció/csere

operáció vált szükségessé. Látható, hogy a Grade 3-as szövődmények száma kevesebb, mint az UAcomp+ szövődmények száma. Ez azért van, mert 5 esetben (12,8\%) a reintervenció, rekonstrukció nem volt elegendő, és végül graftectomia (Grade 4.) vált szükségessé, 14 esetben $(35,9 \%)$ pedig a betegeket az enyhe (Grade 1.) vagy a középsúlyos (Grade 2.) csoportba soroltuk, mert elegendő volt a radiológiai intervenció az urológiai szövődmény megoldására, de más ok miatt szükség volt reoperációra (Grade 2.). A ballonos uretertágítás $(n=4)$ egyik esetben sem volt elsőként választott eljárás, minden esetben DJ-behelyezés előzte meg. I betegnél (25\%) volt elegendő a mútét nélküli megoldás. I betegnél DJ-, majd NS-behelyezés történt ureterszúkület miatt, amelyet ballonos tágítás követett, végül ureterrekonstrukció történt, sikerrel. Összességében a 27 , nem sebészeti intervencióban részesülő recipiens közül 14 esetben $(51,9 \%)$ elegendő volt a nem sebészeti beavatkozás, 10 esetben $(37,0 \%)$ pedig az egyszeri DJ-sín-behelyezés 

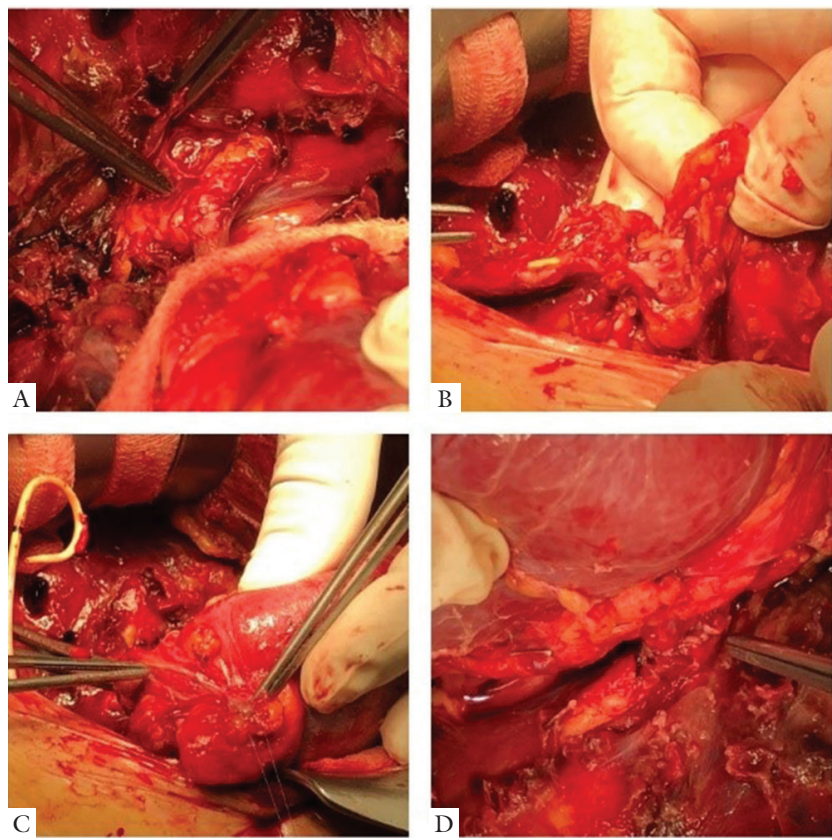

1. ábra

Ureternecrosis utáni rekonstrukció veseátültetésnél, pyelourete-
rostomia

megoldotta az ureterszövődményt mútét nélkül. Az 1 . ábra egy ureternecrosis miatt végzett rekonstrukciós mútétet szemléltet: az A képen látszik, hogy az UUanastomosis ép. Feltárva a régiót, a B kép mutatja, hogy a donorureter a varratsortól proximálisan elhalt, a laesión át láthatóvá vált a DJ-sín. A C képen a reszekált donorureter után előtúnő pyelon nyílása látszik, melyet tartóöltésekkel már elláttunk, majd, ahogy a D képen látható, anastomosis készült a recipiensureterrel (pyeloureterostomia).

A Clavien-beosztás függvényében mért kumulatív beteg- és grafttúléléseket a 6. táblázat és a 2. ábra részletezi. A teljes vizsgált populációra vonatkozó l éves kumu-

\section{Grafttúlélés veseátültetés után}

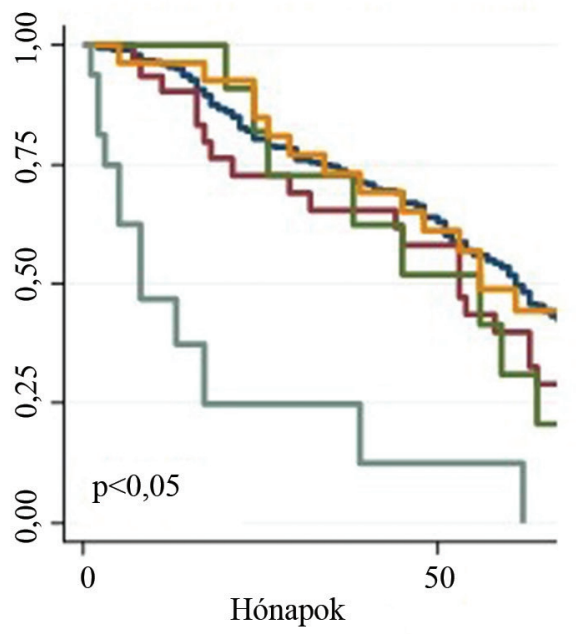

Grade 0 .

Grade 1.
6. táblázat A veseátültetést követő 1 és 5 éves beteg- és grafttúlélések a vizsgált populáció összes esetszámát tekintve és a módosított Clavien-beosztást alapul véve

\begin{tabular}{lc|c|c|c}
\hline & \multicolumn{2}{c|}{ Beteg } & \multicolumn{2}{c}{ Graft } \\
\cline { 2 - 5 } & 1 év & 5 év & 1 év & 5 év \\
\hline Grade 0. & $96 \%$ & $92 \%$ & $95 \%$ & $87 \%$ \\
Grade 1. & $94 \%$ & $87 \%$ & $84 \%$ & $73 \%$ \\
Grade 2. & $92 \%$ & $75 \%$ & $92 \%$ & $75 \%$ \\
Grade 3. & $100 \%$ & $76 \%$ & $96 \%$ & $63 \%$ \\
Grade 4. & $79 \%$ & $65 \%$ & $21 \%$ & $5,0 \%$ \\
\hline Összes & $95 \%$ & $87 \%$ & $90 \%$ & $77 \%$ \\
\hline
\end{tabular}

latív ( $\mathrm{n}=406)$ betegtúlélés $94,6 \%(\mathrm{n}=384)$, a grafttúlélés $88,9 \%(\mathrm{n}=361)$. Az 5 éves kumulatív $(\mathrm{n}=219)$ betegtúlélés 87,2\% (191), a grafttúlélés 76,7\% (n=168). Vizsgálatunkból kiemelhető, hogy azoknál a betegeknél, akiknél Grade 1-es, 2-es, 3-as súlyossági fokozatú, a mútéti beavatkozással összefüggésbe hozható technikai szövődmény alakult ki, de ezt adekvát kezelés követte, az 1 és 5 éves kumulatív beteg- és grafttúlélés nem rosszabb a teljesen szövődménymentes (Grade 0 .) esetekhez viszonyítva (6. táblázat). A betegtúlélésre az általunk vizsgált szövődmények szignifikáns hatással vannak $(\mathrm{p}<0,05)$, a graft túlélésénél számolt p-érték pedig határérték-szignifikancia $(\mathrm{p}=0,0725)$ (2. ábra).

\section{Következtetés}

Az irodalomban a veseátültetés után kialakult és elsősorban a mütéti beavatkozás technikai részével összefüggésbe hozható szövődmények osztályozása nem egységes. Vannak tanulmányok, melyek a sebészeti beavatkozást igénylő szövődményeket elemzik [8], mások kimondottan az ureterszövődményeket [9], vagy immunológiai

Betegtúlélés veseátültetés után

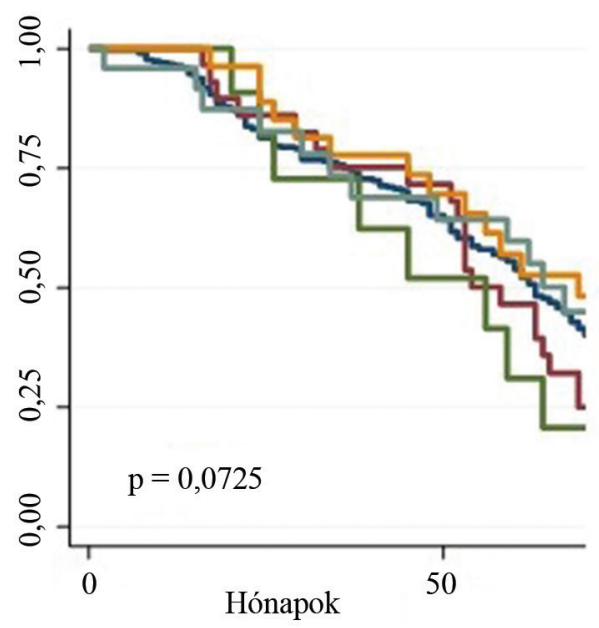

Grade 2. Grade 3. Grade 4.

2. ábra | Graft- és betegtúlélés a veseátültetés után intervenciót igénylő szövődmények tekintetében 
[10], fertőzéses [11], illetve cardiovascularis szövődmények [12] elemzésével foglalkoznak.

Viszonylag új témaként fellelhető a BK-vírus (BKV) mint az ureternecrosis egy rizikótényezője, veseátültetés után. A vesetranszplantált populáció kitettsége nagy a BKV-fertőzés felé az immunszupprimált állapot miatt. Christiadi és mtsai egy 2019-ben megjelent metaanalízisben tanulmányozták a BKV-fertőzés kialakulásának gyakoriságát, diagnosztikáját, és intervenciós protokollt is javasoltak [13]. A modern immunszuppressziós érában a BKV-fertőzés gyakorisága vesetranszplantált betegeknél 1-10\%. Rizikótényezője lehet az alacsony HLAegyezés, kadáver donor, hosszabb CIT, nőnemú donor férfi recipienssel, magas recipiensi életkor, uretersínezés, visszatérő akut rejekciós epizódok, ATG-, TAC-, MMF-, együttes immunszuppressziós terápia alkalmazása. A BKV-indukált nephropathia diagnózisában arany standardnak számít a veseallograft szövettani mintavételezése (túbiopszia), melyből immunhisztokémiai folyamatokkal a tubularis epithelialis sejtek virális degenerációja kimutatható. Kevésbé invazív módszerként a PCR-vizsgálatnak van létjogosultsága, mely 100\%-os szenzitivitással, 90\% körüli specificitással azonosítja vérből a vírust, vizeletból pedig 100\%-os szenzitivitással és 92\%-os specificitással. A BKV terápiájának vezetése szakmai nehézségeket okozhat. Az irodalmi források többsége az immunszuppresszív szerek dózisának csökkentését javasolja, ez azonban növeli az akut rejekció veszélyét, ami a graftés betegtúlélést csökkentheti. A BKV-fertőzés összefüggését feltételezik az ureterszúkületek, illetve ureternecrosisok egy részének hátterében. Több esetben találtunk BKV-pozitivitást ureterszúkületeknél és vesefunkcióromlással járó eseteknél, ez irányú kutatásaink folyamatban vannak [13]. Klinikánkon vér- és vizeletmintából PCR-vizsgálattal történnek BKV irányú vizsgálatok. Kezdetben ezeket válogatott esetekben végeztük, jelenleg pedig minden betegnél 3., 6., 12. hónapnál.

A korábban már részletezett, általunk módosított Clavien-klasszifikáció alapján a 406 veseátültetett közül 307 beteg $(75,6 \%)$ volt teljesen szövődménymentes, további $32(7,9 \%)$ klinikailag enyhe, a beteg számára ismételt beavatkozással vagy maradandó problémával nem járó esettel együtt $339(83,5 \%)$. Amennyiben a múvesekezeléssel járó potenciális cardiovascularis szövődményeket és kötöttséget mérlegeljük, akkor elfogadhatók a veseátültetés után kialakuló, egyszeri beavatkozást vagy meghosszabbított kórházi bennfekvést igénylő, de a beteg számára a továbbiakban az életminőséget nem befolyásoló, a beültetett vesét nem veszélyeztető, közepes (Grade 2.) súlyosságú szövődmények (például lymphokele, hegsérv, hasfalat is érintő sebszétválás, NPWT-igényü sebgennyedés). Ezekkel együtt már 351 beteg $(86,5 \%)$ esetén tekinthetjük a veseátültetést klinikailag teljesen sikeresnek, ami kifejezetten jó arány.

A vérzéses szövődményeknél fontos megemlíteni, hogy az uraemiás betegek jelentős része a meglevő cardialis társbetegségek miatt véralvadásgátló gyógyszert szed. Ráadásul ezeket többnyire az idős betegeknél észleljük, akiknél jellemzően a koszorúerek mellett a vasculatura más területein is észlelhetó az arteriosclerosis.

A transzplantáló sebészek nagy része egyetért abban, hogy a mútét utáni kisebb (elsősorban szisztémás) vérzések okozta kockázat és ennek elhárítása még mindig kisebb problémát jelent, mint a graft thrombosisa. Az uraemia mellett a véralvadás is kompromittált, ezért a posztoperatív thrombosisprofilaxis fontosságát nem lehet eléggé hangsúlyozni. A beültetett vese artériás és vénás thrombosisának megelőzésében nagy szerepe van az LMWH használatának. Ez azonban magában rejti a vérzés rizikójának emelkedését [14]. A megfelelő haemostasis-egyensúly megtalálása nem minden esetben egyszerú, különösen DGF esetén.

$\mathrm{Az}$ ureterszövődményekért a beültetés során vétett technikai hibák (megcsavarodás, szúk varrat stb.) mellett a leginkább a donáció technikája, a reperfúziónál történő preparálás és az ureteranastomosis típusa lehet felelős $[5,15]$. Az úgynevezett „golden triangle” (arany háromszög: az ureter, a vese és az a. renalis közötti mesoureter-régió) felelős a graft ureter és a pyelon vérellátásáert [16], melynek sérülése a beültetés után ureternecrosishoz vezethet. Tanulmányunkban a vizeletcsorgás aránya a teljes populációra nézve 4,7\% $(\mathrm{n}=19)$, az ureterszúkület aránya anyagunkban $7,6 \%(\mathrm{n}=31)$ volt, ami megfelel a nemzetközi irodalomban közölt adatoknak. Streeter és mtsai 1535 veseátültetést vizsgáló tanulmányában a vizeletcsorgás és a primer ureterelzáródás aránya $6,5 \%$ [16]. A vizsgált periódusban Klinikánkon csökkent az ureterrel kapcsolatos szövődmények aránya: 2010 -ben $11,4 \%, 2019$-ben $5,0 \%$ volt.

Általánosságban véve elmondható, hogy irodalmi adatok alapján a transzplantáció más területén is összefügg a technikai szövődmények aránya a centrumban végzett mútétek mennyiségével és az operatőrök gyakorlottságával is. Minél nagyobb forgalmú egy centrum, arányaiban annál kisebb a szövődmények elófordulása $[17,18]$. Nemes és mtsai májátültetések tekintetében vizsgálták két európai centrum (magyar, holland) szövődményarányainak összehasonlítását, amely az irodalomban az egyik első, ilyen jellegű összehasonlító tanulmány volt. A tanulmány kifejti, hogy a túlélést befolyásolja egyes centrumok eltérô mútéti protokollja, sztenthasználata, az immunszuppresszív sémák [17]. Egy másik munkacsoporttal Nemes és mtsai egy magyar centrum tapasztalatait tanulmányozva írták le, hogy a májátültetés utáni a. hepatica thombosis aránya (mint az egyik legsúlyosabb sebészeti szövődmény) - a recipiens adottságai (a cirrhosis mértéke), a mútét időzítése (éjszaka) és a donormáj anatómiai sajátosságai (többes és/vagy gracilis artéria) mellett - összefüggést mutat a sebész gyakorlatának mértékével is. Ugyanakkor ezek külön nem, csak abban az esetben jelentettek szignifikáns rizikófaktort, ha közös változóként, kockázati pontszám formájában rendelték a mútéthez [18]. A mi tanulmányunk nem tér ki az egyes operatőrök eredményeinek összehasonlítására. Figye- 
lembe véve azonban, hogy a mútéti technikák fajtája önmagában nem korrelál szignifikánsan a szövődmények kialakulásával, illetve tekintettel arra, hogy a tanulmány célja a belső minőségbiztosítási kontroll is, ez irányú adatfeldolgozások most is zajlanak. Kutatásunkat tervezzük kibővíteni abban az irányban is, hogy a májátültetéshez hasonlóan több rizikótényezőt kombinált hatásként értelmezve kockázati pontszámot alkalmazzunk a veseátültetés esetén is. Ezután ismét érdemes lehet összehasonlítani az eredményeket.

A recipiensek BMI-je bizonyítottan rossz hatással van a túlélésre [19], és növelheti a sebészeti szövődmények számát [20]. Az általunk vizsgált populációnál a BMI a Grade 1-es és a Grade 2-es csoportban volt a legmagasabb, ám az elhízás szignifikánsan nem korrelált a szövődmények kialakulásával; a sebfertőzések azonban az előbb említett Grade 1-es csoportba tartoznak, ami klinikailag magyarázható.

Tanulmányunkban a vascularis (intervenció vérzés, thrombosis, AV fistula miatt) szövődmények aránya öszszesítve $6,7 \%(\mathrm{n}=27)$ volt a vizsgálati periódusban, ami megegyezik a nemzetközi irodalomban olvasott adatokkal. Ezen belül a beültetett vesét veszélyeztető a. renalis thrombosis előfordulási gyakorisága 2,2\% ( $n=9)$, az a. renalis stenosisé pedig $1,5 \%(\mathrm{n}=6)$ volt. Lempinen és mtsai 1670 esetszámú tanulmányában a vascularis szövődmények aránya 3,4\% [21], Salebipour és mtsai tanulmányában pedig 8,86\% volt egy 1500 fós tanulmányban [22]. A szövődmények nem sebészeti, minimálinvazív terápiája az intervenciós radiológia segítségével egyre nagyobb teret hódít. Ez magában foglalja számos vascularis és urológiai szövődmény kezelését, valamint folyadékgyülemek drenálását. A vascularis szövődmények terápiája közül a leggyakoribb az a. renalis stenosis első vonalbeli kezelésének tekintendő PTA-ballonos tágítás, szükség esetén sztenteléssel. További intervenciós radiológiai módszerekkel kezelhetók azok az aneurysmák, melyek az iliacalis erek és a graft éranastomosisai között helyezkednek el. Ilyen megoldás lehet az endovascularis sztentgraft beültetése. Az urológiai szövődmények közül a leggyakoribb az ureteralis szúküulet, melyet a magas sikerráta (58-95\%) és az alacsony szövődményarány miatt elsőként választandó beavatkozásokkal kezelnek: percutan nephrostoma, ballonos tágítás, DJ-sztent behelyezése, ritkán pedig öntáguló fémsztent behelyezése. A graft körüli folyadékgyülemet ultrahang- vagy CT-vezérelten drenálják, melynek kiváltó oka lehet nyirokfolyás, haematoma, vizeletcsorgás, következményesen tályog [23]. Klinikánkon az ureterkomplikációk utáni radiológiai beavatkozásokat túlnyomórészt urológusok végzik, a preferált beavatkozás ureterszúkület esetén a cisztoszkóp segítségével felvezetett DJ-sín. A vascularis szövődmények és folyadékgyülemek intervencióját radiológusok végzik. Az ureteranastomosis szövődményeinek megelözéséhez hatékony lehet az uretersín használata, melyet Klinikánkon is alkalmazunk. Wilson és mtsai profilaktikusan alkalmaztak uretersínt, és összehasonlították a költ- ség-haszon arányt a szövődmények tekintetében [24]. Bár az UTI-k száma magasabb, a major urológiai szövődmények aránya kisebb a sztent nélküli csoporthoz képest. A DJ-sín használata csökkenti a nyomást az anastomosisnál, valamint az ureter megtörését is segít megelőzni. Klinikánk gyakorlatában, amennyiben a mütét során a recipiensureter könnyen azonosítható a retroperitoneumban, és nincs tudomásunk az anamnézisben kontraindikáló tényezőről (például uretert, ureterszájadékot érintő urológiai mútét, ismert reflux), továbbá a DJ-sín könnyedén levezethető a hólyagba, akkor ('endto-side') UU-t készítünk tovafutó, felszívódó sebészi varrattal. Amennyiben bármilyen nehézség, kétely adódik mútét közben a fentieket illetően, úgy ureteroneocystostomia a választandó technika. Az ureterszövődmények túlnyomó része a posztoperatív első hónapban jelentkezik, melyek megfelelő kezelés, sebészi és/vagy urológiai intervenció mellett nem jelentenek graftvesztést. A különböző ureterimplantációs mütéttechnikák és a szövődmények kialakulása között nincs szignifikáns összefüggés, viszont jelentős az operatőr gyakorlata az adott technikában. Klinikánk gyakorlatában a fiatal, veseátültetés iránt érdeklődő sebészek mindkét technikát megtanulják. Irodalmi adatokkal összevetve, minél magasabb az esetszám, annál alacsonyabb a szövődmények aránya, Neri és mtsai 1142 veseátültetést vizsgáló tanulmányával összevetve [25]. Saját anyagunkban az UU után észlelt ureterszúkület aránya 6,4\% $(\mathrm{n}=13)$, míg az UNS-technikánál ez 9,0\% (n=18). Ez ugyan jelentős eltérésnek látszik, de a különbség statisztikailag nem szignifikáns. A vizeletcsorgás aránya is alacsonyabb UUanastomosis után, az UNS-technikával összehasonlítva. Lényeges megemlíteni, hogy az UN-anastomosis kivitelezésében vannak egyéni különbségek, különösen az úgynevezett antirefluxöltés alkalmazásában. A klasszikus leírás alapján [26] a varrat elkészültét követően a hólyag muscularis rétegét az anastomosis és az ureter utolsó 1-2 cm-es szakasza felett összehúzva „tunnelizálni” kell oly módon, hogy az ne szúkítsen, ugyanakkor megakadályozza a retrográd vizeletáramlást a hólyag felól. Ezt az egyensúlyt meg kell találni, és önmagában az is okozhat később stenosist, ha ez nem tökéletes. Az UN előnye ugyanakkor, hogy a hólyag jó vérellátása miatt a gyógyulás még akkor is biztosított, ha a donorureter végének vérellátása nem tökéletes. Az UU-anastomosis egyik elönye, hogy fiziológiásabb, a vesicoureteralis átmenet intakt marad, mivel a donorureter e fölött kerül beültetésre a recipiensureterbe. Az UU-varrat érzékeny pontja, hogy sikeres elkészítéséhez a donorureter vége is jó vérellátással kell, hogy rendelkezzen, a varratot figyelmesen, apró, nem traumatizáló öltésekkel kell elkészíteni. Az első a megfelelő donorszerv-eltávolítási technikával, illetve a beültetés előtt méretre vágással (nem túl hosszú) kivédhető, az utóbbi megfelelő gyakorlattal elsajátítható. $\mathrm{Az}$ ureter sínezése nemcsak az anastomosis védelmében előnyös, hanem azért is, hogy a donorureter a retroperitoneumban megfelelően elhelyezkedve nem törik meg, 
hegesedik, szúkül be az anastomosis felett sem. A sínezés - átmeneti - hátránya, hogy eltávolításáig megszünteti a vesicoureteralis átmeneti szelep múködését, és aszcendáló fertőzésnek nyithat utat. Az UU-anastomosis elkészítését azért érdemes megtanulni a veseátültetéssel foglalkozó sebészeknek, mert kiváló eszköz akkor is, ha egy korábbi UN-anastomosis hegesedése után kell rekonstrukciót végezni. Ekkor az érintett rész reszekciója után, a röviden maradt donorureter ép csonkja és a recipiensureternek a heges mútéti területtől, a hólyagtól távolabb eső része között készülhet varrat. Hasznos lehet még ez a technika minden olyan esetben is, amikor a donorureter rövid, és nem ér le feszülésmentesen a hólyaghoz (szervkivétel során sérült ureter, fordított állásban beültetett vese, élő donor).

A korai ureterszövődményekre többnyire a mútéti drénen keresztül észlelt vizeletcsorgás hívja fel a figyelmet. A mintából mért kreatininérték nemcsak a diagnózis igazolására alkalmas, hanem ismétlés esetén a változást is mutatja. Egyes betegeknél ugyanis jelentős mennyiségű nyirokcsorgás is lehetséges, így önmagában a drén hozamának ismerete nem mindig elégséges. Amennyiben a vizeletcsorgás mennyisége nem nagy (max. 5-700 ml), akkor néhány nap megfigyelést nem tartunk kockázatosnak. A mennyiség csökkenése esetén nem avatkozunk be, különösen, ha a folyadék kreatinintartalma is csökken. Egyúttal képalkotó vizsgálatok is készülnek, ultrahang a pyelontágulat és a perirenalis folyadékgyülem kizárására, illetve röntgen az uretersín helyzetének tisztázására. Néhány esetben veseizotóp igazolta a vizelet kilépését. Amennyiben a drén hozama stagnál vagy emelkedik, illetve bizonyítást nyer, hogy nem megfelelően van pozicionálva az uretersín, urológussal konzultálunk. Az első lépésben cisztoszkópia (szükség esetén ureteroszkópia) történik, ismételt, vastagabb, új sín felhelyezése vagy a régi repozíciója. Mútétet a korai időszakban akkor végzünk, ha ez sikertelen, illetve abban a néhány esetben, amikor a drénen megjelenő vizelet mennyisége eleve meghaladta a tolerálható menynyiséget (>700 ml/24 h). A késői (>30 nap) ureterszövődmények jellemzően stenosist jelentettek, és pyelontágulat, vizeletmennyiség-csökkenés formájában jelentek meg. Az egyes esetek individuális elbíráláson esnek át. Törekszünk a nem operatív megoldást előtérbe helyezni, ha ez sikertelen, akkor tervezetten reoperáció történik. A reoperációk során a sebésznek megfelelően improvizálnia kell, amint ezt az 5. táblázat és az 1. ábra mutatja.

A túlélési adatok tekintetében mind a beteg, mind a graft túlélésére szignifikáns hatással lehetnek az intervenciót igénylő szövődmények. Kiemelendő, hogy a súlyos (Grade 3.) szövődményekig bezárólag, a beteg- és grafttúlélés szignifikánsan nem rosszabb a szövődménymentes populációhoz képest. Szövődmények felmerülése esetén fontos a mielőbbi diagnosztika és az időben alkalmazott, adekvát korrekció. Emellett a graft várható túlélése a szövődménymentes populációhoz hasonló [27].
A szakmai alázatot a saját hibák korrekciójában is fontosnak tartjuk. Ilyen lépés volt 2013-ban a sokszínú mútéti technológiai variációk megőrzése, a vénaplastica végzése jobb oldali vese esetén, a DJ-sín alkalmazásának bevezetése az UU-anastomosisok végzése során, a betegágy melletti ('first aid') Doppler-vizsgálat készségének elsajátítása a veseátültetésben dolgozó sebészek részéről. A minőségbiztosítás részének tartjuk a szövődmények időről időre történő publikálását is, annak érdekében, hogy az értékelhetővé váljék, illetve ösztönözzön a további fejlesztésre. Saját gyakorlatunkban az elmúlt 10 év adatainak elemzése azt mutatta, hogy a kidolgozott mútéti technika, a protokoll szerint végzett perioperatív kezelés, a társszakmákkal történő aktív konzultáció nagy szerepet játszik a szövődmények arányának alacsonyan tartásában. Eredményeink nemzetközi összehasonlításban is megállják a helyüket.

Anyagi támogatás: A közlemény megírása, illetve a kapcsolódó kutatómunka anyagi támogatásban nem részesült.

Szerzői munkamegosztás: I. L.: Témaválasztás, adatgyűjtés, a dolgozat megírása, irodalomkutatás, interpretáció. F. R., K. D. Á., K. Zs.: Mütétek végzése. Z. G.: Az adatgyüjtés megszervezése, irodalomkutatás. Sz. G. J.: Statisztikai elemzés. K. M.: Az adatgyüjtésben való közremúködés. F. T.: Az urológiai szövődmények ellátása. T. J., V. R., B. I.: Radiológiai intervenció. N. B.: Témaválasztási javaslat, az adatgyújtés megszervezése, ellenőrzése, eredmények kiértékelése, irodalomkutatás, mentori korrekciók. A cikk végleges változatát valamennyi szerző elolvasta és jóváhagyta.

Érdekeltségek: A szerzőknek nincsenek érdekeltségeik.

\section{Köszönetnyilvánítás}

Köszönettel tartozunk a Debreceni Egyetem veseátültetésben részt vevő munkatársainak és a szövődmények elhárításában segítséget nyújtó társszakmák képviselőinek.

\section{Irodalom}

[1] Ogutmen B, Yildirim A, Sever MS, et al. Health-related quality of life after kidney transplantation in comparison intermittent hemodialysis, peritoneal dialysis, and normal controls. Transplant Proc. 2006; 38: 419-421.

[2] Illés A, Nemes B, Kovács S, et al. Examination of attitudes towards transplantation among patients with chronic renal failure. [A krónikus vesebetegek transzplantációval kapcsolatos attitúdjeinek vizsgálata.] Orv Hetil. 2018; 159: 1898-1904. [Hungarian]

[3] Clavien PA, Camargo CA Jr, Croxford R, et al. Definition and classification of negative outcomes in solid organ transplantation. Application in liver transplantation. Ann Surg. 1994; 220: 109120.

[4] Röhl L, Ziegler M. Uretero-neocystostomy in kidney transplan tation. [Die Uretero-Neocystostomie bei der Nierentransplantation.] Urologe 1969; 8: 116-119. [German] 
[5] Buttigieg J, Agius-Anastasi A, Sharma A, et al. Early urological complications after kidney transplantation: an overview. World J Transplant. 2018; 8: 142-149.

[6] Tóth F, Zádori G, Fedor R, et al. A single-center experience of allograft nephrectomies following kidney transplantation. Transplant Proc. 2016; 48: 2552-2554.

[7] Tóth F, Zádori G, Fedor R, et al. Allograft nephrectomy - a single-center experience. [Graftectomiák a debreceni vesetranszplantációs programban.] Orv Hetil. 2016; 157: 964-970. [Hungarian]

[8] Szabo-Pap M, Zadori G, Fedor R, et al. Surgical complications following kidney transplantations: a single-center study in Hungary. Transplant Proc. 2016; 48: 2548-2551.

[9] Rigg KM, Proud G, Taylor RM, et al. Urological complications following renal transplantation. A study of 1016 consecutive transplants from a single center. Transpl Int. 1994; 7: 120-126.

[10] Nemes B, P Szabó R, Bidiga L, et al. Antibody-mediated rejection: challenge of the treatment in kidney transplantated patients. [Antitestmediált rejekció: kihívás a veseátültetett betegek kezelésében.] Orv Hetil. 2018; 159: 1913-1929. [Hungarian]

[11] Illesy L, Szabo-Pap M, Toth F, et al. Bacterial infections after kidney transplantation: a single-center experience. Transplant Proc. 2016; 48: 2540-2543

[12] Rao NN, Coates PT. Cardiovascular disease after kidney transplant. Semin Nephrol. 2018; 38: 291-297.

[13] Christiadi D, Karpe KM, Walters GD. Interventions for BK virus infection in kidney transplant recipients. Cochrane Database Syst Rev. 2019; 5: CD013344.

[14] Mathis AS, Davé N, Shah NK, et al. Bleeding and thrombosis in high-risk renal transplantation candidates using heparin. Ann Pharmacother. 2004; 38: 537-543.

[15] Keller H, Nöldge G, Wilms H, et al. Incidence, diagnosis, and treatment of ureteric stenosis in 1298 renal transplant patients. Transpl Int. 1994; 7: 253-257.

[16] Streeter EH, Little DM, Cranston DW, et al. The urological complications of renal transplantation: a series of 1535 patients. BJU Int. 2002; 90: 627-634.

[17] Nemes B, Polak W, Ther G, et al. Analysis of differences in outcome of two European liver transplant centers. Transpl Int. 2006; 19: 372-380.
[18] Nemes B, Gaman G, Gelley F, et al. Technical risk factors for hepatic artery thrombosis after orthotopic liver transplantation: the Hungarian experience. Transplant Proc. 2013; 45: 36913694.

[19] Grosso G, Corona D, Mistretta A, et al. The role of obesity in kidney transplantation outcome. Transplant Proc. 2012; 44: 1864-1868.

[20] Zrim S, Furlong T, Grace BS, et al. Body mass index and postoperative complications in kidney transplant recipients. Nephrology (Carlton) 2012; 17: 582-587.

[21] Lempinen M, Stenman J, Kyllönen L, et al. Surgical complications following 1670 consecutive adult renal transplantations: a single center study. Scand J Surg. 2015; 104: 254-259.

[22] Salehipour M, Salahi H, Jalaeian H, et al. Vascular complications following 1500 consecutive living and cadaveric donor renal transplantations: a single center study. Saudi J Kidney Dis Transpl. 2009; 20: 570-572.

[23] Iezzi R, la Torre MF, Santoro M, et al. Interventional radiological treatment of renal transplant complications: a pictorial review. Korean J Radiol. 2015; 16: 593-603.

[24] Wilson CH, Bhatti AA, Rix DA, et al. Routine intraoperative stenting for renal transplant recipients. Transplantation 2005; 80: $877-882$.

[25] Neri F, Tsivian M, Coccolini F, et al. Urological complications after kidney transplantation: experience of more than 1,000 transplantations. Transplant Proc 2009; 41: 1224-1226.

[26] Murray JE, Harrison JH. Surgical management of fifty patients with kidney transplants including eighteen pairs of twins. Am J Surg. 1963; 105: 205-218.

[27] Król R, Ziaja J, Chudek J, et al. Surgical treatment of urological complications after kidney transplantation. Transplant Proc. 2006; 38: 127-130.

(Illésy Lóránt dr., Debrecen, Móricz Zs. körút 22., 4032 e-mail: illesy.lorant@med.unideb.hu)

A cikk a Creative Commons Attribution 4.0 International License (https://creativecommons.org/licenses/by/4.0/) feltételei szerint publikált Open Access közlemény, melynek szellemében a cikk bármilyen médiumban szabadon felhasználható, megosztható és újraközölhetö, feltéve, hogy az eredeti szerző és a közlés helye, illetve a CC License linkje és az esetlegesen végrehajtott módosítások feltüntetésre kerülnek. (SID_1) 